\title{
MODEL PENGEMBANGAN POJOK WIRAUSAHA MAHASISWA SEBAGAI BUSINESS CENTRE BERBASIS ON LINE WEB MARKETING DI UNIVERSITAS MUHAMMADIYAH RIAU
}

\author{
Jusnita $^{1}$, Siti Samsiah ${ }^{2}$, Asrinda Amalia ${ }^{3}$, Edo Ariebi ${ }^{4}$ \\ ${ }^{1}$ Jusnita Universitas Muhammadiyah Riau \\ ${ }^{2}$ Siti Samsiah Universitas Muhammadiyah Riau \\ ${ }^{3}$ Asrinda Amalia Universitas Muhammadiyah Riau \\ ${ }^{4}$ Edo Ariebi Universitas Muhammadiyah Riau \\ ${ }^{1}$ Email : jusnita@umri.ac.id
}

\begin{abstract}
ABSTRAK
Pengabdian ini bertujuan untuk merekomendasikan model Bisnis Center yang diorientasikan menjadi sebuah inovasi. Adapun populasi yang digunakan adalah mahasiswa Universitas Muhammadiyah Riau (UMRI) yang secara tergabung berkumpul sebagai tenant (calon wirausaha binaan) dalam sebuah Bisnis Center, yakni sebanyak 20 mahasiswa. Metode yang digunakan adalah workshop kewirausahan, model pembelajaran, dan Pelatihan internet, website, dan blogger serta membuka jaringan kerja on line. Data yang diperoleh dianalisis dengan menggunakan analisis deskriptif, persentase, dan statistik non paremeter dengan Microsoft excel. Hasil pengabdian, ada beberapa pokok persoalan yang dapat disimpulkan bahwa 1) perencanaan pemesanan dan perkembangan model Bisnis Center siap dilaksanakan dengan didasarkan pada teori dalam bidang studi secara terkonsep dan terstruktur dengan baik. 2) Proses perkembangan model Bisnis Center diselenggarakan dengan melalui tiga tahapan, yaitu: pendahuluan, mengembangkan model, dan uji coba model. 3) Model Bisnis Center yang mendorong keterampilan kewirausahaan terhadap mahasiswa UMRI adalah model Bisnis Center yang diorientasikan untuk menjadi inovasi dan mensyaratkan keahlian kewirausahaan di dalamnya. 4) Model Bisnis Center yang direkomendasikan di UMRI memungkinkan terciptanya pembentukan keterampilan kewirausahaan pada tenant (calon wirausaha binaan).
\end{abstract}

Kata Kunci: Model Bisnis Center, On Line Web Marketing, Capacity Building, Wirausaha Mandiri

\section{PENDAHULUAN}

Pendidikan kewirausahaan semakin ditingkatkan di perguruan tinggi dengan menanamkan jiwa dan semangat kewirausahaan dengan metode dan strategi yang membuat mahasiswa tertarik untuk berwirausaha agar lulusan perguruan tinggi mampu mandiri. Pendidikan kewirausahaan di perguruan tinggi diharapkan bisa menyiapkan mahasiswa untuk berani mandiri, tidak lagi terfokus menjadi pencari kerja. Data pengangguran terdidik di Indonesia menunjukkan, semakin tinggi pendidikan seseorang, semakin rendah kemandirian dan semangat kewirausahaannya.

Menurut data Badan Pusat Statistik tahun 2017, jumlah lulusan perguruan tinggi yang bekerja adalah 12,24 persen. Jumlah tersebut setara dengan 14,57 juta dari 118,41 juta pekerja diseluruh Indonesia. Sementara pengangguran lulusan perguruan tinggi mencapai 11,19 persen, atau setara dengan 787 ribu dari total yang tidak memiliki pekerjaan. Tingginya angka pengangguran yang ditamatkan pendidikan tinggi di Indonesia menjadi fenomena di perguruan tinggi. 
Gambar 1.1. Pojok Wirausaha Mahasiswa

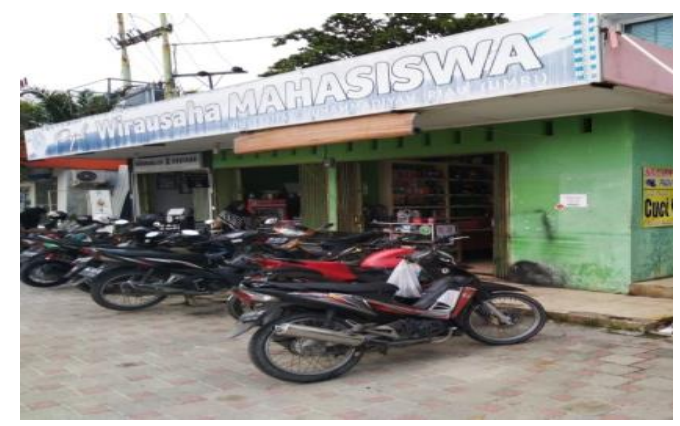

Untuk menjawab persoalan tersebut di setiap perguruan tinggi saat ini sudah mulai mirintis program pendidikan kewirausahaan. Program Pengembangan Kewirausahaan dilaksanakan untuk menumbuhkembangkan jiwa kewirausahaan mahasiswa dan juga staf pengajar serta diharapkan menjadi wahana pengintegrasian secara sinergi antara penguasaan sains dan teknologi dengan jiwa kewirausahaan.

Gambar 1.2. Peserta Program Mahasiswa Wirausaha

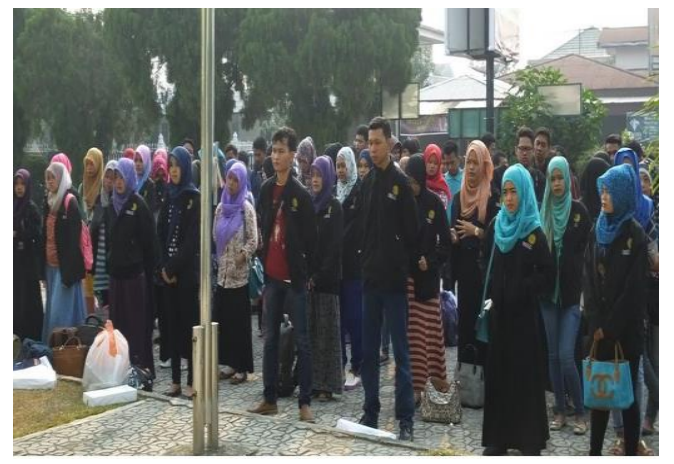

Selain itu diharapkan pula hasil-hasil penelitian dan pengembangan tidak hanya bernilai akademis saja, namun mempunyai nilai tambah bagi kemandirian perekonomian bangsa. Kewirausahaan, dapat didefinisikan sebagai kemampuan melihat dan menilai kesempatan-kesempatan (peluang) bisnis serta kemampuan mengoptimalisasikan sumber daya dan mengambil tindakan serta bermotivasi tinggi dalam mengambil resiko dalam rangka mensukseskan bisnisnya.
Pendidikan kewirausahaan di Indonesia masih kurang memperoleh perhatian yang cukup memadai, baik dunia pendidikan maupun masyarakat. Banyak pendidik yang kurang memperhatikan sikap dan perilaku kewirausahaan sasaran didik, baik di sekolahsekolah menengah, maupun di pendidikan tinggi. Orientasi mereka, pada umumnya hanya pada menyiapkan tenaga kerja. Peranan perguruan tinggi dalam memotivasi mahasiswa menjadi seorang wirausahawan muda sangat penting dalam menumbuhkan jumlah wirausahawan. Dengan meningkatnya wirausahawan dari kalangan sarjana akan mengurangi pertambahan jumlah pengangguran bahkan menambah jumlah lapangan pekerjaan. Pertanyaannya adalah bagaimana pihak perguruan tinggi dapat mencetak wirausahawan muda.

Wirausaha mahasiswa di Universitas Muhammadiyah Riau sudah berkembang sejak tahun 2014 hingga sekarang, dengan dukungan dana Kemenristekdikti melalui Program Mahasiswa Wirausaha (PMW). Tujuan dari PMW ini adalah untuk menumbuhkan motivasi berwirausaha dikalangan mahasiswa, menumbuh kembangkan wirausaha-wirausaha baru yang berpendidikan tinggi dengan menciptakan unit-unit bisnis baru yang berbasis IPTEK serta membangun jejaring bisnis antar ilmu pengetahuan, teknologi dan seni dengan membangun jaringan antar pelaku bisnis, khususnya antara wirausaha pemula dan pengusaha yang sudah mapan.

Jumlah usaha mahasiswa 2017 yang potensial saat ini tercatat di UPT kewirausahan ada 20 unit usaha, yang terdiri dari 3 usaha kuliner dan 17 usaha jasa/produksi yang berbasis IPTEK. Namun unit-unit usaha tersebut tidak berjalan sebagaimana mestinya, 
hal ini disebabkan karakter mahasiswa dan lulusan yang masih berorientasi job seeker 3omputer3g job creator.

Pojok kewirausahaan mahasiswa merupakan salah satu unit bisnis yang bertahan sampai sekarang, dimana posisinya cukup strategis berada didepan gerbang pintu masuk UMRI. Beberapa unit bisnis yang sudah ada di Pojok Kewirausahaan Mahasiswa ini antara lain: (1). Bengkel dan cucian sepeda motor, (2). Jasa 3omputer dan fhoto copy dan (3). Jasa cucian helm sepeda motor. Tantangan yang dihadapi oleh Pojok Wirausaha Mahasiswa UMRI sebagai wadah wirausaha mahasiswa mandiri antara lain; 1). Belum memiliki wadah capacity building sebagai bekal kemampuan berwirausaha kepada para mahasiswa dan lulusannya 2) Kompetensi pengelola masih konvensional di tengah persaingan usaha yang berbasis on line web marketing, 3). Belum adanya model yang baku dalam pengembangan Pojok Wirausaha sebagai Business Center berbasis on line web marketing di UMRI dan 4). Keterbatasan biaya/modal dan sarana prasarana untuk operasional usaha.

\section{METODE}

Metode yang digunakan dalam pengabdian ini adalah sebagai berikut;

\section{Workshop Kewirausahaan}

Metode yang digunakan dalam pelatihan ini melalui tatap muka, dimana narasumber menjelaskan definisi, pengertian, konsepkonsep berwirausaha meliputi teori-teori tentang kewirausahaan, manajemen pengolahan bisnis, strategi pemasaran, manajemen produksi, manajemen keuangan, bisnis plan.

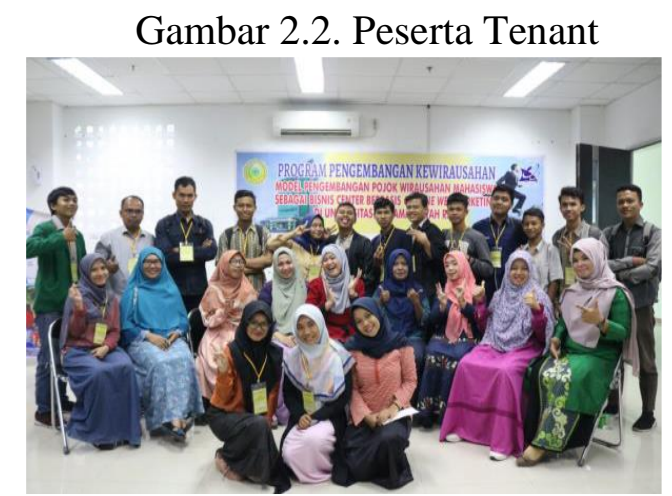

Supaya suasana pelatihan bisa lebih aktif dan hidup maka dilakukan diskusi kelompok; dimana tenant dibagi dalam kelompok yang memiliki usaha serupa atau sejenis, antara lain kelompok usaha makanan dan minuman, kelompok usaha perbengkelan, kelompok usaha perdagangan. Dalam diskusi ini tenant didampingi oleh narasumber agar tenant berani mengemukakan pendapatnya dan mendorong untuk berpikir kreatif.

\section{Model Pembelajaran}

Metode pendekatan pendampingan wirausaha di Universitas Muhammadiyah telah disusun secara terstruktur dan berkesinambungan dengan metode Coaching NLP (Neuro Linguistic Program).

Gambar 2.3. Coaching Tenant

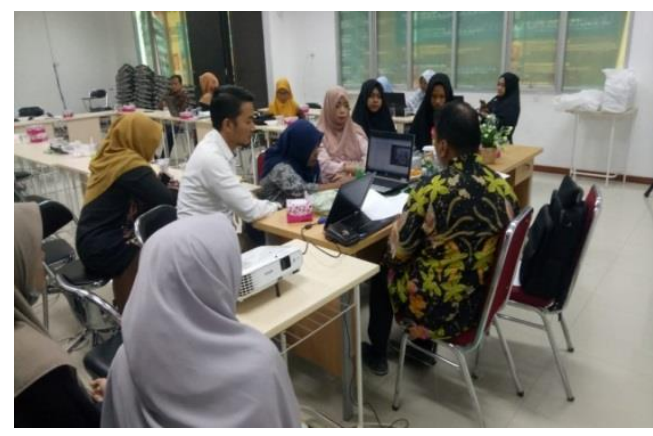

Pada metode ini akan mengidentifikasi kondisi awal usaha peserta dengan membagi masalah usaha tenant menjadi lima masalah yang lebih psesifik yaitu profil usaha, profil produk, pemasaran, pembukuan 
dan keuangan. Metode ini dlakukan dengan cara melakukan Focus Group Discussion (FGD) antara tenant, dosen pengampu mata kuliah kewirausahaan dan praktisi serta berupaya menggali kekuatan sumber daya internal dan eksternal masing-masing tenant.

\section{Metode Magang Pada Industri Mitra}

Magang pada industri mitra dimana selama magang, tenant bekerja sebagai karyawan di perusahaan mitra.

Gambar 2.4. Tenant Magang

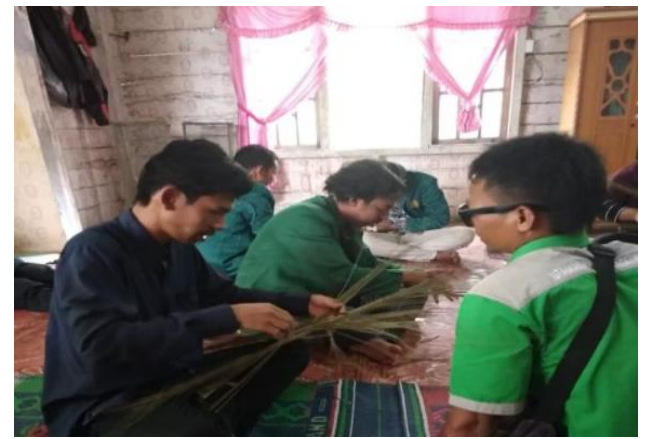

Diharapkan tenant mendapatkan pengalaman tentang proses produksi, baik secara kualitas maupun kuantitas produksi, teknologi yang digunakan dalam proses produksi, membidik pangsa pasar, strategi pemasaran dan kendala-kendala yang dihadapi dalam pengelolaan suatu usaha bisnis dan bagaimana cara penyelesaian masalah. Selesai dari magang, diharapkan tenant memiliki ideide kreatif dan inovatif dalam mengembangkan usaha bisnisnya dan dapat membuat Business Plan yang lebih baik dan dapat dipraktekkan sebagai wirausaha mandiri. Pola kegiatan magang ini disebut juga dengan Learning by Doing.

\section{Metode Pembimbingan Terhadap Tenant}

Tenant dibimbing oleh tim pelaksana PPK UMRI yang berpengalaman dibidang kewirausahaan dan mitra usaha. Tenant diberi

kesempatan bila ingin konsultasi tentang usaha yang baru dirintis.

Gambar 2.5. Pembimbing Tenant

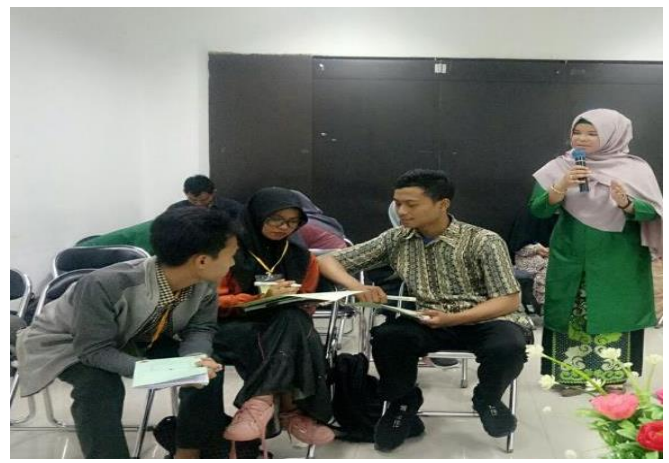

Tim pelaksana PPK secara aktif terus memotivasi tenant untuk tidak mudah menyerah, apabila menghadapi masalah atau kegagalan, karena kegagalan adalah awal dari sebuah keberhasilan. Bimbingan dan pendampingan dilakukan secara efektif oleh tim pelaksana PPK setiap minggu dan dilakukan evaluasi terhadap apa yang sudah dilakukan oleh tenant.

\section{Metode Pengawasan Terhadap Tenant}

Tim pelaksana PPK UMRI melakukan pengawasan kepada tenant mulai dari pelatihan, praktek kewirausahaan, magang di perusahaan mitra, pembuatan proposal business plan sampai dengan pengelolaan usaha baru yang dirintis. Pengawasan terhadap tenant diupayakan bersifat edukatif artinya tenant tidak merasa selalu diawasi dan takut bila terjadi kesalahan, tetap diupayakan tim pelaksana bisa membimbing tenant, mengarahkan tenant dan memberikan pembetulan bila terjadi kesalahan

\section{Teknik Pembiayaan Usaha Tenant Dan Bantuan Teknologi}

Setelah tenant berhasil membuat business plan yang baik, maka tenant memulai merintis usaha baru. Pada awalnya tenant 
membiayai usaha dengan modal sendiri, namun untuk kelangsungan usaha, tenant membutuhkan tambahan dana. Sehingga tim pelaksana PPK UMRI memberikan bantuan teknologi secara bertahap yang diberikan berdasarkan penilaian prospektus usaha tenant. Tim pelaksana PPK UMRI juga ikut mengupayakan untuk mendapatkan CSR dari perusahaan-perusahaan yang dapat disalurkan kepada tenant yang membutuhkan dan juga mengarahkan tenant untuk membuat proposal PMW yang di upload ke simlitabmas Kemenristekdikti untuk mendapatkan bantuan dana hibah.

\section{Metode Penyelesaian Masalah}

Dalam merintis usaha baru, tentunya tenant menghadapi banyak masalah. Oleh karena itu peran tim pelaksana PPK sangat dibutuhkan untuk membantu tenant dalam menyelesaikan masalahan

\section{HASIL DAN PEMBAHASAN}

\section{Perencanaan Pengembangan Model}

Perencanaan

penyusunan dan

pengembangan model dilakukan berdasarkan: a). kajian teoritis dan b). fakta empiris di lapangan baik secara konseptual maupun structural. Pertama, kajian teoritis terhadap model Bisnis Center menggunakan analisis SWOT. Hasil analisis SWOT menunjukkan bahwa Bisnis Center UMRI memiliki kekuatan yang lebih dominan dibanding kelemahannya, dan peluang yang lebih besar dibanding ancamannya.

Gambar 3.1. Tenant Biophonik

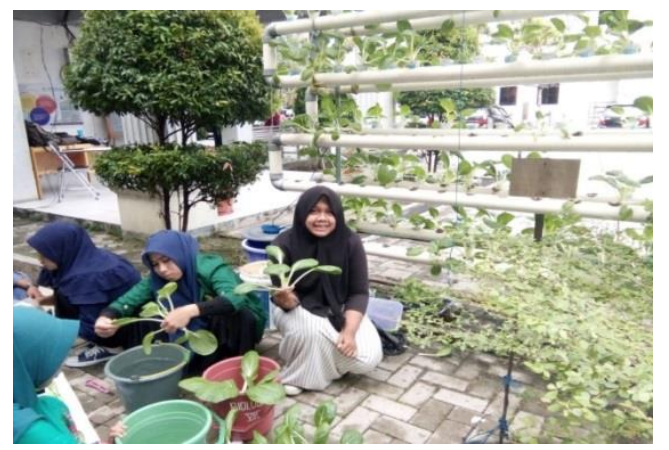

Dengan memperhatikan hasil analisis SWOT, posisi Bisnis Center UMRI berada pada posisi Keadaan Bertumbuh, yaitu memanfaatkan seoptimal mungkin kekuatan memperoleh peluang-peluang yang tersedia di luar lingkungan Bisnis Center UMRI.

Kedua, fakta empiris konseptual menunjukkan bahwa sarana pendukung pelaksanaan Bisnis Center UMRI belum sepenuhnya tersedia, penumbuhan dan penetasan usaha melalui penyediaan fasilitas sarana dan prasarana belum dapat dilakukan dengan baik, struktur dan infrastruktur kurang memadai, administrasi belum dilakukan secara tertib dan rapi, akses jaringan usaha dan informasi serta akses jaringan modal atau pembiayaan di kalangan mahasiswa binaan (tenant) dirasakan masih kurang.

Gambar 3.2. Produk Tenant Jam Serat Tebu

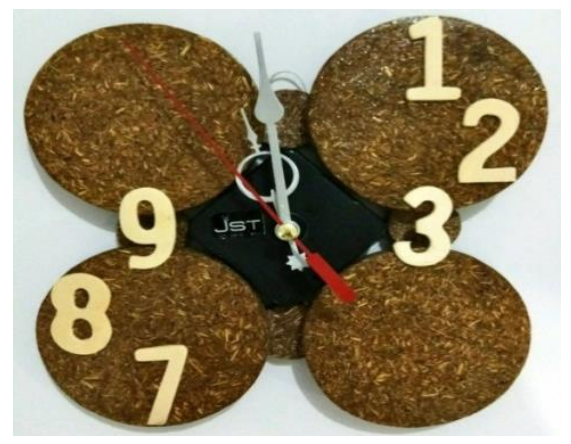

Adapun fakta empiris struktural menunjukan bahwa Bisnis Center UMRI sebagai sebuah sistem yang terintegrasi di bawah pengelolaan penrguruan tinggi. Keberadaannya memiliki nilai strategis dalam mengaplikasikan konsep link and match. Selain itu, Bisnis Center UMRI berfungsi sebagai wadah bagi pembinaan dan pengembangan kewirausahaan secara akademik yang tetap mengacu pada pengembangan sumberdaya manusia berdasarkan konsep-konsep akademik. Hasil pengabdian kepada masyarakat ini mendukung penelitian Suwandi (2008) yang mengevaluasi model-model Bisnis Center yang dikembangkan oleh perguruan tinggi negeri di Indonesia, yang menyimpulkan bahwa seluruh

Sinar Sang Surya Vol. 2 No. 2 Februari 2019 | 5 
perguruan tinggi sebelum menentukan model yang akan digunakan terlebih dahulu menyusun berbagai perencanaan model, sehingga dalam pelaksanaan pengembangan model dapat terlaksana dengan baik.

\section{Proses Penyusunan dan Pengembangan Model}

Proses penyusunan dan pengembangan model Bisnis Center di Universitas Muhamamdiyah Riau, dapat disimpulkan sebagai berikut: (a). Langkah pertama, melakukan studi pendahuluan untuk mengembangkan pramodel Bisnis Center yang meliputi studi kepustakaan/literature, dan survey lapangan. Berdasarkan kedua hal tersebut dilakukan analisis SWOT dan analisis empiris baik secara konseptual maupun structural. Langkah pertama ini menghasilkan pramodel Bisnis Center; (b). Langkah kedua, melakukan pengembangan model, yang meliputi langkah validasi pramodel yang sudah ada oleh ahli dan pengujian model Bisnis Center, baik skala terbatas maupun skala luas. Berdasarkan langkah-langkah tersebut terwujudlah model Bisnis Center yang telah teruji secara teoritik dan empirik; (c). Langkah ketiga, melakukan uji model dengan membandingkan antara model yang yang diujicobakan skup terbatas dan model yang diujicobakan dengan skup luas, sehingga tercipta model akhir Bisnis Center UMRI; (d) Langkah keempat, implementasi model sehingga menghasilkan output dan outcome.

\section{Model Bisnis Center yang Dikembangkan}

Model Bisnis Center UMRI yang berorientasi inovasi dalam bentuk pelatihan Bisnis Center sirup dari siledri (sirdasel), Sabun Mahasiswa Kimia (samakiri), Sedu_Bento, Bioponik, Jam Serat Tebu (JST) dan bengkel sepeda motor yang bertujuan menumbuhkan kompetensi kewirausahaan dapat dijelaskan sebagai berikut;

Prinsip dasar model, sebagai suatu system model pelatihan yang berkelanjutan, dalam arti peserta pelatihan tidak hanya lulus pelatihan akan tetapi yang bersangkutan disiapkan untuk menjadi wirausahawan yang handal dan mandiri. Karakteristik model meliputi:a) pelatihan Bisnis Center merupakan kesatuan program pembelajaran bagi mahasiswa, b). sebagai bentuk pelatihan Bisnis Center UMRI yang dibangun atas dasar peluang dan potensi sumberdaya yang dimiliki UMRI, c) pelatihan Bisnis Center dilakukan sesuai dengan minat mahasiswa, d) model ini memerlukan kesediaan Pembina, pendamping dan kemitraan usaha dalam menjalankan bisnis baru, dan e). menekankan nilai kejujuran, keuletan, kecerdasan dalam memanfaatkan peluang, mampu melakukan analisis resiko dan berani mencoba menjadi bagian yang tidak terpisahkan dari pengembangan usaha bisnis. Komponen model meliputi: a). masukan input; b). proses Bisnis Center yang terdiri dari teori dan pelatihan; c). output; d). outcome: e). monitoring, evaluasi dan tindak lanjut. Prosedural operasional pelatihan model Bisnis Center UMRI meliputi: a) Menjaring Raw input yaitu mahasiswa semester IV (empat), VI (enam) atau VII (tujuh) yang telah lulus mata kuliah kewirausahaan dan alumni, (b) Setelah mendapatkan raw input, mereka diberi pelatihan Bisnis Center sebagai bentuk interaksi peserta Bisnis Center, sarana dan sumber belajar untuk melahirkan pengetahuan, keterampilan dan kompetensi kewirausahaan. Untuk lebih jelasnya dapat dilihat model berikut;

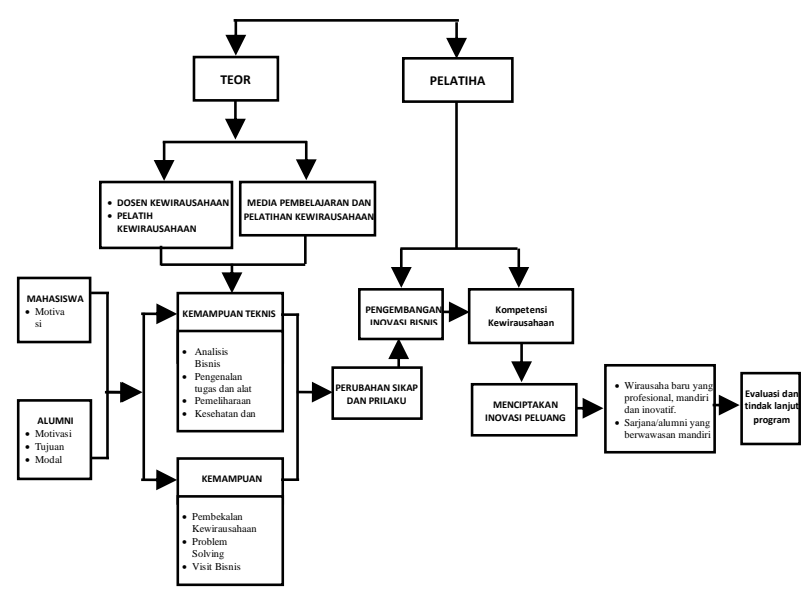

Sinar Sang Surya Vol. 2 No. 2 Februari 2019 | 6 
Setelah pelatihan teori keterampilan selesai, mereka dikelompokkan dalam unit pengembangan dan inovasi pada Bisnis Center UMRI, (d). Selanjutnya Bisnis Center menghasilkan output yaitu meningkatnya pengetahuan, sikap, keterampilan dan aktivitas peserta Bisnis Center yang aktif dalam kegiatan Bisnis Center yang meliputi; kompetensi inti kewirausahaan, kecakapan, keberhasilan, kerjasama dan mempraktikan hasil pelatihan; (e) Pada tahap akhir dihasilkan outcome yaitu sarjana/alumni sebagai wirausahawan baru yang professional, berwawasan global, mandiri dan inovatif, mampu menciptakan peluang usaha sesuai hasil pelatihan; (f) untuk memantapkan proses Bisnis Center dilakukan monitoring, evaluasi, dan tindak lanjut sebagai alat control terhadap keberhasilan proses Bisnis Center dan upaya perbaikan dan inovasi bisnis sebagai turunan dari Bisnis Center UMRI.

Hasil pengabdian kepada masyarkat ini mendukung model yang dikembangkan oleh Lacho (2010), Kordnaeij, et.al. (2011).

\section{Evaluasi dan Tindak Lanjut, untuk Mengetahui Efektivitas Model.}

Berdasarkan hasil evaluasi dapat disimpulkan bahwa model Bisnis Center UMRI berorientasi inovasi pada kelompok eksperimen dapat dikatakan efektif. Efektivitas pembelajaran tersebut dapat dilihat dari: (a). Tercapainya tujuan pembelajaran sesuai dengan prioritas tujuan yang ditetapkan mahasiswa binaan dengan pengelola Bisnis Center; (b). Memiliki kesesuaian dengan kebutuhan belajar peserta inkubasi; (c). Berpengaruh positif terhadap peningkatan pengetahuan, sikap, perilaku dan keterampilan, sangat mendukung terhadap peningkatan kompetensi kewirausahaan; (d). Dapat menggali, mengoptimalkan dan menyalurkan potensi, bakat dan minat peserta binaan Bisnis Center; (e). Membantu meningkatkan dan mempercepat proses pembelajaran yang lebih kondusif; (f). Mempunyai dampak yang baik bagi mahasiswa, sehingga mereka memiliki minat untuk menyebarluaskan pengetahuan yang telah dimiliki 4 . kepada orang lain, memiliki motivasi, tanggung jawab, kreativitas, inovasi, dan percaya diri yang lebih tinggi.

\section{KESIMPULAN DAN SARAN}

Berdasarkan hasil uji coba model, analisis data, dan pembahasan, kesimpulan hasil pengabdian kepada masyarakat merekomendasi model Bisnis Center UMRI yang berorientasi bisnis dapat dirumuskan sebagai berikut:

1. Perencanaan
pengembangan
model dilakukan berdasarkan : a). kajian teoritis dan b). fakta empiris di lapangan baik secara konseptual maupun structural. Kajian teoritis terhadap model Bisnis Center menggunakan analisis SWOT. Hasil perhitungan SWOT menunjukkan bahwa Bisnis Center UMRI berada pada posisi Keadaan Bertumbuh, yaitu memanfaatkan seoptimal mungkin kekuatan memperoleh peluang-peluang yang tersedia di luar lingkungan Bisnis Center UMRI.

2. Proses penyusunan dan pengembangan model Bisnis Center UMRI, dapat disimpulkan sebagai berikut: Pertama, melakukan studi pendahuluan. Kedua, melakukan pengembangan model. Ketiga, melakukan uji model dengan membandingkan antara model yang diujicobakan skup terbatas, dan model yang diujicobakan dengan skup luas, sehingga tercipta model akhir Bisnis Center UMRI. Keempat, implementasi model sehingga menghasilkan output dan outcome.

3. Model Bisnis Center UMRI yang berorientasi inovasi, sebagai suatu system model pelatihan yang berkelanjutan, dalam arti peserta pelatihan tidak hanya lulus pelatihan akan tetapi yang bersangkutan disiapkan untuk menjadi wirausahawan yang handal dam mandiri. Komponen model meliputi: a) masukan input; b). proses Bisnis Center yang terdiri dari teori

dan pelatihan; c). output; d). outcome; e). monitoring, evaluasi dan tindak lanjut.

. Model Bisnis Center UMRI berprientasi inovasi pada kelompok eksperimen dapat dikatakan efektif. Efektivitas pembelajaran tersebut dapat dilihat dari: tercapainya 
tujuan pembelajaran sesuai dengan prioritas tujuan yang ditetapkan mahasiswa binaan dengan pengelola Bisnis Center.

\section{UCAPAN TERIMAKASIH}

Penulis mengucapkan terimakasih kepada DRPM Kemenristekdikti yang telah mendanai Program Pengembangan Kewirausahan (PPK), Lembaga Penelitian dan Pengabdian Kepada Masyarakat (LPPM) Universitas Muhammadiyah Riau (UMRI) dan Fakultas Teknik UMRI yang telah memberikan dukungan finansial terhadap kegiatan Pengabdian Kepada Masyarakat. Terimakasih kepada tenant sebagai Mitra dalam kegiatan PPK yang telah ikut berpartisipasi dan bekerjasama dalam pelaksanan kegiatan.

\section{DAFTAR PUSTAKA}

Harto, D., Pratiwi, S. R., Utomo, M. N., \& Rahmawati, M. (2019). Penerapan Internet Marketing Dalam Meningkatkan Pendapatan Pada UMKM. Jurnal Pengabdian Dan Pemberdayaan Masyarakat, 3(1), 39-45.

Ragimun, Sudaryanto, \& Wijayanti, R. R. (2015). Strategi Pemberdayaan UMKM Menghadapi Pasar Bebas Asean. Web Kementerian Keuangan, 1-32.

Pearce, J. ., \& Robinson, R. . (2013). Strategic

Management: Formulation,

Implementation, and Control Manajemen

Strategis (12th) (12th ed.). Jakarta

Selatan: MC Graw Hill.

Kordnaeij, et.al., 2011, Orogins of Entrepreneirial Opportunitiesine-Banking, Journal of Global Entrepreneurship Research, Winter \& Spring, 2011, Vol. 1 No. 1 pp 21-33

Kementerian Hukum dan HAM, I. (2008). UndangUndang No 20 Tahun 2008 Tentang Usaha Mikro, Kecil, Menengah. (20), 1-24.
Pujiastuti, Eny Endah, dkk. (2008). Perpaduan Antara Teori dengan Praktek pada Model Inkubator Bisnis. Makalah 